\title{
KORELASI KONDISI FISIK RUMAH DAN KARAKTERISTIK BALITA DENGAN KASUS CAMPAK DI KOTA SURABAYA
}

\section{THE CORRELATION OF HOUSE'S PHYSICAL CONDITION AND TODDLER CHARACTERISTICS WITH MEASLES CASE IN SURABAYA CITY}

\author{
Birayu Jeny Afdhalash ${ }^{1}$, Retno Adriyani ${ }^{1}$ \\ ${ }^{1}$ Departemen Kesehatan Lingkungan \\ Fakultas Kesehatan Masyarakat, Universitas Airlangga, Surabaya, Indonesia \\ Alamat Korespondensi: Birayu Jeny Afdhalash \\ Email: birayu.jeny@gmail.com
}

\begin{abstract}
There were 61 confirmed cases of measles in Surabaya in 2016, whereas in January-May 2017 there were 52 confirmed cases of measles. Many factors that could affect the incidence of measles include physical conditions of the house (lighting, occupancy density, and ventilation area) and toddler characteristics (age, gender, immunization status of measles, exclusive breastfeeding and contact history ). The purpose of this study was to analyze the relationship between physical conditions of the house and toddler characteristics with the incidence of measles in Surabaya. It was an observational study in the form of case study control design. This study used all confirmed measles cases on toddlers during January-May 2017 which had been proven by IgM laboratory examination by Health Office of Surabaya City. The results of this study indicated that there was a significant correlation between lighting (approx.sig=0.025), occupancy density (approx.sig=0.001), immunization status (approx.sig=0.136) and contact history with measles incident on toddlers in Surabaya. The conclusions of this study were the conditions of lighting, density, measles immunization status and contact history were significant risk factors for the incidence of measles. Mothers should maintain the cleanliness of the home environment, and toddler's bedroom should get enough sunlight and have good air circulation by opening windows to prevent the growth of measles virus.
\end{abstract}

Keywords: physical conditions of the house, toddler characteristics, mother characteristics, measles

\begin{abstract}
ABSTRAK
Kasus campak konfirmasi di Kota Surabaya pada tahun 2016 sebanyak 61 kasus, sedangkan pada tahun 2017 selama bulan Januari-Mei terdapat 52 kasus campak konfirmasi. Banyak faktor yang dapat berpengaruh terhadap kasus campak antara lain kondisi fisik rumah (pencahayaan, kepadatan hunian dan luas ventilasi) serta karakteristik balita (status imunisasi campak, pemberian ASI eksklusif, umur balita, jenis kelamin, serta riwayat kontak). Penelitian ini bertujuan untuk menganalisis hubungan antara kondisi fisik rumah serta karakteristik balita dengan kasus campak di Kota Surabaya. Dalam penelitian ini menggunakan jenis penelitian observasional dengan desain studi kasus kontrol. Sampel dalam penelitian ini adalah seluruh kasus campak konfirmasi pada balita selama bulan Januari-Mei 2017 yang telah dibuktikan dengan adanya pemeriksaan laboratorium IgM oleh Dinas Kesehatan Kota Surabaya. Hasil penelitian menunjukkan bahwa ada hubungan yang signifikan antara pencahayaan (approx.sig=0.025), kepadatan hunian (approx.sig=0.001), status imunisasi (approx.sig=0.136) serta riwayat kontak dengan penderita campak terhadap kasus campak pada balita di Kota Surabaya. Kesimpulan dari penelitian ini adalah kondisi pencahayaan, kepadatan hunian, riwayat kontak, serta status imunisasi campak adalah faktor risiko yang signifikan terhadap kasus campak. Sebaiknya ibu menjaga kebersihan lingkungan rumah dengan rajin membuka jendela kamar tidur balita agar cahaya matahari dapat masuk dan terjadi pertukaran udara untuk mencegah pertumbuhan virus campak.
\end{abstract}

Kata kunci: kondisi fisik rumah, karakteristik balita, karakteristik ibu, campak

\section{PENDAHULUAN}

Penyakit campak merupakan penyakit endemik di berbagai negara khususnya negara berkembang. Di seluruh dunia angka kesakitan campak mencapai 5-
10 kasus per 10.000 dengan jumlah kematian 1-3 kasus per 1000 orang. Menurut WHO (2017), selama tahun 2015, telah terjadi 134.200 kasus kematian yang diakibatkan oleh campak (367 kematian per hari dan 15 kematian per jam) sedangkan 
tahun 2016 kembali meningkat menjadi 189.3775 kasus dan di tahun 2017 selama bulan Januari hingga Mei telah terjadi kasus campak sebanyak 40.576 kasus.

Data WHO tahun 2017 menyebutkan, Indonesia menempati urutan ke 6 dari 10 besar negara dengan kasus campak terbanyak di dunia, yaitu sebanyak 2301 kasus. Menurut Kemenkes RI (2015), tahun 2013 kasus campak di Indonesia dilaporkan sebanyak 11.521 kasus, akan tetapi meningkat pada tahun 2014 menjadi 12.943 kasus. Di Indonesia, penyakit campak menempati urutan ke-5 penyakit yang menyerang anak-anak terutama pada bayi dan balita.

Penyakit campak menjadi salah satu penyakit infeksi yang masuk dalam prioritas masalah kesehatan yang harus segera ditangani di Indonesia karena mudah menularnya penyakit campak sehingga dapat menimbulkan kejadian luar biasa (KLB) ataupun wabah. Peringkat ke-4 penyakit yang dapat menyebabkan KLB di Indonesia adalah campak setelah DBD, diare dan chikungunya, sehingga campak masuk ke dalam daftar prioritas penyakit potensial terjadi KLB (Dinkes Provinsi Jatim, 2013).

Di Provinsi Jawa Timur kasus campak mengalami peningkatan mulai tahun 2009 hingga tahun 2011. Pada tahun 2011 pemerintah melakukan program "Kampanye Campak" yang bertujuan untuk mengurangi jumlah kasus campak yang terus meningkat. Dari kampanye yang telah dilakukan, di tahun 2012 kasus campak semakin menurun menjadi 1.085 kasus dan Provinsi Jawa Timur menjadi salah satu provinsi dengan jumlah kasus campak urutan ke-4 dari 33 provinsi. Akan tetapi tahun 2013, kasus campak kembali mengalami peningkatan hingga 2.529 kasus dan diikuti dengan meningkatnya urutan Provinsi Jawa Timur menjadi urutan ke-3. Pada tahun 2014 kasus campak kembali menurun menjadi 762 kasus. (Dinkes Provinsi Jatim, 2014).

Rekomendasi dari WHO mengenai kriteria KLB campak y aitu minimal terjadi 5 kasus campak/100.000 populasi. di Indonesia sendiri kategori KLB campak pasti atau campak konfirmasi yaitu apabila minimal ada 2 spesimen positif IgM campak berdasarkan hasil pemeriksaan laboratorium pada penderita campak klinis. Pemeriksaan laboratorium ini sangat penting karena gejala penyakit campak hampir sama dengan penyakit lainnya seperti rubella.

Campak di Kota Surabaya belum termasuk dalam kriteria KLB karena dari kurang lebih 2.862.406 jiwa penduduk selama tahun 2016 terdapat kasus campak konfirmasi sebanyak 61 kasus dengan jumlah kematian atau Case Fatality Rate (CFR) 0\%. Akan tetapi jumlah tersebut tidak dapat diabaikan begitu saja, karena pada tahun 2017 kasus campak konfirmasi pada bulan Januari-Mei telah mencapai angka 52 kasus.

Penyakit campak dapat dipengaruhi oleh berbagai faktor antara lain faktor lingkungan serta karakteristik anak. Berdasarkan penelitian Sutaryana (2002), faktor lingkungan yang memiliki hubungan dengan kasus campak yaitu luas ventilasi, kepadatan hunian dan pencahayaan dalam rumah. Kurangnya ventilasi, pencahayaan serta padatnya hunian khususnya di kamar balita dapat memengaruhi keberadaan virus campak di udara. Semakin padat hunian rumah maka akan semakin mempercepat dan mempermudah penularan virus campak (Setiawan, 2008). Menurut Widoyono (2011), virus campak ini mudah hancur oleh sinar ultraviolet, sehingga diperlukan pencahayaan yang baik agar virus ini tidak bertahan di udara.

Berdasarkan penelitian yang dilakukan oleh Mujiati, et al (2015) dan Giarsawan (2012), faktor risiko yang memiliki hubungan dengan kasus campak antara lain pekerjaan ibu, riwayat pemberian ASI, status imunisasi, riwayat kontak, penghasilan keluarga dan kepadatan hunian. Frekuensi pemberian imunisasi campak yaitu diberikan satu kali saat usia anak antara 9-11 bulan. Penyakit 
campak dapat menyebabkan kematian apabila dipicu dengan terjadinya komplikasi penyakit yang timbul karena daya tahan tubuh anak yang menderita campak menurun.

Pemerintah juga telah melakukan berbagai upaya untuk mengurangi kasus campak salah satunya dengan mengadakan imunisasi Measles and Rubella (MR) secara serentak di seluruh Indonesia pada bulan Agustus - September 2017 pada fasilitas pelayanan kesehatan terdekat seperti Puskemas dan Posyandu. Promosi kesegatan terkait program ini juga telah digalakkan untuk menumbuhkan kesadaran masyarakat. Program ini diharapkan dapat mengurangi kasus campak yang dapat menyerang anak dan balita. Tujuan penelitian ini untuk menganalisis hubungan antara kondisi fisik rumah dan karakteristik balita dengan kasus campak di Kota Surabaya.

\section{METODE PENELITIAN}

Dalam penelitian ini menggunakan jenis penelitian penelitian observasional serta rancang bangun penelitian berupa desain studi kasus kontrol. Menurut Suradi (2002), penelitian kasus kontrol adalah penelitian epidemiologis observasional yang mempelajari hubungan antara penyakit atau kondisi kesehatan tertentu dengan faktor risiko tertentu. Desain penelitian ini dapat digunakan untuk menilai seberapa besar peranan faktor risiko terhadap kejadian penyakit. Sama halnya dalam penelitian ini ingin melihat hubungan antara kondisi fisik rumah serta karakteristik balita dengan terhadap kasus campak di Kota Surabaya. Penelitian ini telah memiliki sertifikat keterangan lolos kaji etik yang diujikan dihadapan komisi etik penelitian kesehatan.

Pengumpulan data dalam penelitian ini menggunakan kuesioner dengan melakukan wawancara langsung kepada responden serta melakukan pengukuran kondisi fisik rumah untuk mendapatakan data primer, sedangkan pengumpulan data sekunder dilakukan dengan mengumpulkan data hasil pemeriksaan laboratorium IgM dari Dinas Kesehatan Kota Surabaya selama bulan Januari-Mei 2017. Kelompok kasus adalah balita penderita campak yang datang ke Puskesmas selama bulan Januari - Mei 2017 yang dibuktikan dengan adanya pemeriksaan laboratorium IgM positif campak oleh Dinas Kesehatan Kota Surabaya dan memenuhi kriteria inklusi, yaitu merupakan warga tetap Kota Surabaya, tidak pindah alamat rumah, dan tidak ada perubahan kondisi fisik rumah mulai saat sakit sampai saat akan diteliti. Kelompok kontrol adalah balita yang tidak sedang menderita campak yang tinggal di sekitar tempat tinggal kelompok kasus. Pada penelitian ini jumlah kasus sebanyak 23 kasus. Namun hanya 20 kasus yang memenuhi kriteria inklusi. Perbandingan sampel kasus dan kontrol yaitu 1:1 maka besar sampel kelompok kontrol sebanyak 20 responden. Dalam pemilihan kelompok kontrol dilakukan matching umur balita yang sama dengan kelompok kasus.

Pengukuran kondisi fisik rumah meliputi pencahayaan dan luas ventilasi dilakukan oleh peneliti. Pengukuran pencahayaan alami dilakukan dengan mengukur intensitas cahaya yang bersumber dari cahaya matahari menggunakan alat luxmeter merk HANNA HI 97500. Sensor cahaya pada luxmeter diletakkan lurus sejajar dengan mata, kemudian angka pada layar panel dibaca apabila telah menunjukkan nilai yang stabil. Data persentase luas ventilasi dihitung dengan membandingkan luas ventilasi dengan luas lantai kamar balita yang diukur dengan mengunakan rollmeter. Data kepadatan hunian diperoleh dengan mewawancarai reponden mengenai jumlah penghuni dan mengukur luas lantai kamar balita, kemudian dihitung lalu hasilnya dicatat pada lembar observasi. Pengumpulan data mengenai karakteristik anak meliputi umur, jenis kelamin, status imunisasi campak, pemberian ASI eksklusif serta riwayat kontak dilakukan dengan melakukan wawancara kepada responden 
yaitu ibu balita. Analisis data dalam penelitian ini menggunakan uji chi square dengan melihat nilai approx sig dan contingency coefficient.

\section{HASIL PENELITIAN}

Kondisi fisik rumah meliputi beberapa variabel yaitu pencahayaan, ventilasi serta kepadatan hunian yang paling dimungkinkan memiliki hubungan atau dapat memengaruhi kasus campak pada balita di Kota Surabaya.

Penilaian variabel pencahayaan dilakukan dengan mengukur intensitas pencahayaan alami yaitu pencahayaan yang bersumber dari cahaya matahari. Hasil dari pengukuran ini dicatat dalam lembar observasi yang telah disiapkan sebelumnya. Terdapat dua kategori penilaian pencahayaan yaitu memenuhi syarat bila intensitas cahaya kurang dari sama dengan 60 lux dan tidak memenuhi syarat bila intensitas cahaya kurang dari 60 lux, sesuai dengan ketentuan dalam Peraturan Menteri Kesehatan Republik Indonesia Nomor 1077/ MENKES/ PER/ V/2011 tentang pedoman penyehatan udara dalam ruang rumah.

$$
\text { Hasil pengukuran variabel }
$$

pencahayaan di kamar balita, dari 40 responden didapatkan hasil bahwa sebanyak $8(34,78 \%)$ kamar balita penderita campak pada kelompok kasus telah memenuhi syarat sedangkan pada kelompok kontrol sebanyak $15(65,22 \%)$ kamar balita telah memenuhi syarat pencahayaan yaitu lebih besar sama dengan 60 lux.

Rata-rata intensitas cahaya dalam kamar balita kelompok kasus yaitu sebesar 40 lux dengan intensitas cahaya tertinggi sebesar 410 lux dan intensitas cahaya terendah sebesar 20 lux, sedangkan pada kelompok kontrol memiliki rata-rata intensitas cahaya dalam kamar balita sebesar 125 lux dengan intensitas cahaya tertinggi sebesar 940 lux dan intensitas cahaya terendah sebesar 15 lux.
Variabel pencahayaan berdasarkan analisis chi square, terdapat hubungan yang signifikan antara pencahayaan dengan kasus campak pada balita di Kota Surabaya (approx.sig $=0,025<0,05$ ) dengan nilai contingency coefficient sebesar 0,334. Nilai contingency coefficient antara 0,200-0,399 menunjukkan korelasi yang lemah. Pada penelitian ini juga didapatkan nilai OR sebesar 4,5 yang berarti balita dengan kamar yang memiliki pencahayaan tidak memenuhi syarat memiliki risiko terjadi penyakit campak 4,5 kali lipat dibandingkan balita dengan kamar yang memiliki pencahayaan yang memenuhi syarat. Intensitas pencahayaan yang diukur dalam penelitian yaitu pencahayaan alami yang bersumber dari cahaya matahari langsung yang masuk ke dalam kamar balita.

Terdapat dua kategori penilaian luas ventilasi yaitu memenuhi syarat apabila luas ventilasi lebih besar sama dengan $10 \%$ dari luas lantai dan tidak memenuhi syarat bila luas ventilasi kurang dari $10 \%$ dari luas lantai mengacu pada Peraturan Menteri Kesehatan Republik Indonesia Nomor 1077/MENKES/PER/V/2011 tentang pedoman penyehatan udara dalam ruang rumah.. Hasil pengukuran luas ventilasi di kamar balita dari 40 responden didapatkan bahwa sebanyak $8(57,14 \%)$ kamar balita pada kelompok kasus telah memenuhi syarat luas ventilasi sedangkan pada kelompok kontrol sebanyak $6(42,86 \%)$ kamar balita telah memenuhi syarat luas ventilasi yaitu lebih besar sama dengan $10 \%$ luas lantai. Variabel luas ventilasi berdasarkan analisis menggunakan chi square menunjukkan tidak terdapat hubungan yang signifikan antara persentase luas ventilasi terhadap kasus campak pada balita (approx.sig $=0,507>0,05$ ). Rata-rata luas ventilasi kamar balita kelompok kasus yaitu $10 \%$ dari luas lantai, sedangkan pada kelompok kontrol, rata-rata luas ventilasi yaitu $8 \%$ luas lantai. 
Tabel 1. Distribusi Pengukuran Pencahayaan Kamar Balita Terhadap Kasus Campak Bulan Januari-Mei 2017 di Kota Surabaya

\begin{tabular}{lcccccc}
\hline \multicolumn{1}{c}{$\begin{array}{c}\text { Intensitas } \\
\text { Cahaya }\end{array}$} & $\mathbf{n}$ & $\begin{array}{c}\text { Kasus } \\
\text { Persentase } \\
(\boldsymbol{\%})\end{array}$ & $\mathbf{n}$ & $\begin{array}{c}\text { Persentase } \\
(\boldsymbol{\%})\end{array}$ & $\mathbf{n}$ & Persentase (\%) \\
\cline { 2 - 5 } $\begin{array}{l}\text { Tidak Memenuhi } \\
\text { Syarat }\end{array}$ & 12 & 70,58 & 5 & 29,42 & 17 & 100,00 \\
\hline Memenuhi Syarat & 8 & 34,78 & 15 & 65,22 & 23 & 100,00 \\
\hline MAX (lux) & 410,0 & & 940,0 & & \\
\hline MIN (lux) & 20,0 & 15,0 & & \\
\hline $\begin{array}{l}\text { RATA-RATA } \\
\text { (lux) }\end{array}$ & 40 & 125 & & \\
\hline
\end{tabular}

Tabel 2. Distribusi Pengukuran Luas Ventilasi Kamar Balita Terhadap Kasus campak Bulan Januari-Mei 2017di Kota Surabaya

\begin{tabular}{|c|c|c|c|c|c|c|}
\hline \multirow[t]{2}{*}{ Luas Ventilasi } & \multicolumn{2}{|r|}{ Kasus } & \multicolumn{2}{|r|}{ Kontrol } & \multicolumn{2}{|r|}{ Total } \\
\hline & $\mathbf{n}$ & $\begin{array}{c}\text { Persentase } \\
(\%)\end{array}$ & $\mathbf{n}$ & $\begin{array}{c}\text { Persentase } \\
(\%)\end{array}$ & $\mathbf{n}$ & Persentase (\%) \\
\hline $\begin{array}{l}\text { Tidak Memenuhi } \\
\text { Syarat }\end{array}$ & 12 & 46,15 & 14 & 53,85 & 26 & 100,0 \\
\hline Memenuhi Syarat & 8 & 57,14 & 6 & 42,86 & 14 & 100,0 \\
\hline MAX & & $17,0 \%$ & & $17,0 \%$ & & \\
\hline MIN & & $5,0 \%$ & & $4,0 \%$ & & \\
\hline RATA-RATA & & $10,0 \%$ & & $8,0 \%$ & & \\
\hline
\end{tabular}

\section{Kepadatan Hunian}

Tabel 3. Distribusi Pengukuran Kepadatan Hunian Kamar Balita Terhadap Kasus campak Bulan Januari-Mei 2017 di Kota Surabaya

\begin{tabular}{|c|c|c|c|c|c|c|}
\hline \multirow{2}{*}{$\begin{array}{c}\text { Kepadatan } \\
\text { Hunian }\end{array}$} & \multicolumn{2}{|c|}{ Kasus } & \multicolumn{2}{|c|}{ Kontrol } & \multicolumn{2}{|r|}{ Total } \\
\hline & $\mathbf{n}$ & $\begin{array}{c}\text { Persentase } \\
(\%)\end{array}$ & $\mathbf{n}$ & $\begin{array}{c}\text { Persentase } \\
(\%)\end{array}$ & $\mathbf{n}$ & Persentase (\%) \\
\hline $\begin{array}{ll}\text { Tidak Memenuhi } \\
\text { Syarat }\end{array}$ & 13 & 81,25 & 3 & 18,75 & 16 & 100,0 \\
\hline Memenuhi Syarat & 7 & 29,17 & 17 & 70,83 & 24 & 100,0 \\
\hline MAX & & 5 & & 4 & & \\
\hline MIN & & 2 & & 2 & & \\
\hline RATA-RATA & & 3 & & 2 & & \\
\hline
\end{tabular}

Pada variabel kepadatan hunian kamar tidur balita dinilai berdasarkan luas lantai dibandingkan dengan jumlah penghuni kamar tidur balita. Terdapat dua ketegori penilaian, yaitu memenuhi syarat jika luas ruang tidur lebih besar sama dengan $8 \mathrm{~m}^{2}$ untuk 2 orang, kecuali anak dengan umur di bawah 5 tahun. Tidak memenuhi syarat jika luas ruang tidur kurang dari $8 \mathrm{~m}^{2}$ untuk 2 orang penghuni, mengacu pada Peraturan Menteri Kesehatan Republik Indonesia Nomor 1077/MENKES/PER/V/2011 mengenai pedoman penyehatan udara dalam ruang rumah.

Hasil pengukuran variabel kepadatan hunian kamar balita pada 40 responden didapatkan hasil bahwa pada kelompok kasus sebanyak $7 \quad(29,17 \%)$ kamar balita memenuhi syarat kepadatan 
hunian, sedangkan pada kelompok kontrol sebanyak $17(70,83 \%)$ telah memiliki kepadatan hunian memenuhi syarat yang Rata-rata kepadatan hunian kamar balita pada kelompok kasus yaitu sebanyak 3 orang/kamar, dengan kepadatan hunian tertinggi yaitu 5 orang tiap kamar dan terendah yaitu 2 orang/kamar. Sedangkan pada kelompok kontrol, rata-rata kepadatan hunian kamar balita yaitu 2 orang/kamar, dengan kepadatan hunian tertinggi yaitu 4orang/kamar dan terendah yaitu 2 orang/kamar. Hal ini disebabkan karena jumlah kamar di rumah responden tidak seimbang dengan jumlah anggota keluarga. Variabel kepadatan hunian berdasarkan analisis statistik chi square terdapat hubungan yang signifikan antara kepadatan hunian dengan kasus campak pada balita (approx.sig $=0,001<0,05$ ) dengan nilai contingency coefficient sebesar 0,455 . Nilai contingency coefficient antara 0,400-0,599 menunjukkan korelasi sedang. Balita yang tinggal di kamar dengan kepadatan yang tinggi memiliki risiko terkena penyakit campak sebesar 10,52 kali dibandingkan dengan balita dengan kepadatan kamar yang tidak padat.

\section{Karakteristik Balita}

Karakteristik balita meliputi beberapa variabel yaitu umur balita, jenis kelamin, status imunisasi, pemberian ASI eksklusif serta riwayat kontak yang paling dimungkinkan memiliki hubungan dengan kasus campak pada balita di Kota Surabaya.

\section{Umur Balita}

Berdasarkan hasil penelitian yang disajikan pada Tabel 4, didapatkan bahwa pada kelompok kasus balita usia lebih dari 3 tahun (37-60 bulan) sebanyak $16(50,0 \%)$ balita dan balita usia 1-3 tahun (12-36 bulan) sebanyak $4(50,0 \%)$. Begitu pula pada kelompok kontrol balita usia lebih dari 3 tahun (37-60 bulan) sebanyak $16(50,0 \%)$ balita dan balita usia 1-3 tahun (12-36 bulan) sebanyak 4 (50,0\%). Hal ini dikarenakan dilakukan matching umur balita pada kelompok kasus dan kontrol. Berdasarkan uji chi square menunjukkan bahwa tidak terdapat hubungan antara umur balita dengan kasus campak (approx.sig=1,000>0,05).

Tabel 4. Analisis Karakteristik Balita Terhadap Kasus Campak pada Balita

\begin{tabular}{|c|c|c|c|c|c|c|}
\hline \multirow{2}{*}{$\begin{array}{c}\text { Karakte } \\
\text { ristik } \\
\text { Balita }\end{array}$} & \multicolumn{2}{|c|}{ Kasus } & \multicolumn{2}{|c|}{$\begin{array}{c}\text { Kontro } \\
1\end{array}$} & \multicolumn{2}{|c|}{$\begin{array}{c}\text { Jumla } \\
\text { h }\end{array}$} \\
\hline & $\mathbf{n}$ & $\%$ & $\mathbf{n}$ & $\%$ & $\mathrm{n}$ & $\%$ \\
\hline \multicolumn{7}{|l|}{ Umur } \\
\hline $\begin{array}{l}1-3 \text { thn } \\
(12-36 \\
\text { bln) }\end{array}$ & 4 & $\begin{array}{r}50, \\
0\end{array}$ & 4 & $\begin{array}{r}50, \\
0\end{array}$ & 8 & $\begin{array}{r}100, \\
0\end{array}$ \\
\hline$>3$ thn & 1 & 50 , & 1 & 50 , & 3 & 100, \\
\hline$(37-60)$ & 6 & 0 & 6 & 0 & 2 & 0 \\
\hline \multicolumn{7}{|l|}{ bln) } \\
\hline \multicolumn{7}{|l|}{ Jenis } \\
\hline \multicolumn{7}{|l|}{ Kelamin } \\
\hline \multirow[t]{2}{*}{ Laki-laki } & 9 & 47 , & 1 & 52, & 1 & 100 , \\
\hline & & 37 & 0 & 63 & 9 & 0 \\
\hline Perempu & 1 & 52 , & 1 & 47, & 2 & 100, \\
\hline an & 1 & 38 & 0 & 62 & 1 & 0 \\
\hline \multicolumn{7}{|c|}{ Status Imunisasi } \\
\hline \multicolumn{7}{|c|}{ Campak } \\
\hline \multirow[t]{2}{*}{ Tidak } & 9 & 81, & 2 & 18, & 1 & 100, \\
\hline & & 82 & & 18 & 1 & 0 \\
\hline \multirow[t]{2}{*}{$\mathrm{Ya}$} & 1 & 37, & 1 & 62 , & 2 & 100, \\
\hline & 1 & 93 & 8 & 07 & 9 & 0 \\
\hline \multicolumn{7}{|l|}{ ASI } \\
\hline \multicolumn{7}{|l|}{ Eksklusif } \\
\hline \multirow[t]{2}{*}{ Tidak } & 1 & 47 , & 1 & 52 , & 2 & 100, \\
\hline & 0 & 62 & 1 & 38 & 1 & 0 \\
\hline \multirow[t]{2}{*}{$\mathrm{Ya}$} & 1 & 52 , & 9 & 47, & 1 & 100 , \\
\hline & 0 & 63 & & 37 & 9 & 0 \\
\hline \multicolumn{7}{|l|}{ Riwayat } \\
\hline \multicolumn{7}{|l|}{ Kontak } \\
\hline \multirow[t]{2}{*}{ Tidak } & 5 & 20 , & 2 & 80 , & 2 & 100, \\
\hline & & 0 & 0 & 0 & 5 & 0 \\
\hline \multirow[t]{2}{*}{$\mathrm{Ya}$} & & 00,0 & 0 & 0,0 & 1 & 100, \\
\hline & & & & & 5 & 0 \\
\hline
\end{tabular}

\section{Jenis Kelamin}

Berdasarkan Tabel 4, hasil penelitian menyatakan bahwa pada kelompok kasus jumlah balita berjenis kelamin laki-laki sebanyak $9(47,37 \%)$ balita dan jumlah balita berjenis kelamin 
perempuan sebanyak $11(52,38 \%)$ balita. Pada kelompok kontrol jumlah balita berjenis kelamin laki-laki sebanyak 10 $(50,0 \%)$ balita, begitu pula dengan balita berjenis kelamin perempuan sebanyak 10 $(50,0 \%)$ balita. Hasil uji chi square menunjukkan tidak ada hubungan yang signifikan antara jenis kelamin balita dengan kasus campak (approx.sig $=0,752>0,05$ ).

\section{Status Imunisasi}

Berdasarkan hasil penelitian yang disajikan pada Tabel 4, didapatkan hasil bahwa pada kelompok kasus sebanyak 11 $(37,93 \%)$ balita telah mendapatkan imunisasi campak usia 9 bulan sedangkan 9 $(81,82 \%)$ balita tidak mendapatkan imunisasi campak usia 9 bulan. Pada kelompok kontrol sebanyak 18 (62,07\%) balita telah mendapat imunisasi campak usia 9 bulan sedangkan $2(18,18 \%)$ balita tidak mendapat imunisasi campak usia 9 bulan. Berdasarkan hasil uji chi square menunjukkan terdapat hubungan yang signifikan antara status imunisasi campak dengan kasus campak (approx.sig $=0,013>0,05)$ dengan nilai contingency coefficient sebesar 0,365 . Nilai contingency coefficient antara 0,200-0,399 menunjukkan korelasi yang lemah. Balita yang tidak mendapatkan imunisasi campak utamanya pada usia 9 bulan akan lebih berisiko 7,36 kali terkena campak dibandingkan dengan balita yang mendapatkan imunisasi campak utamanya pada usia 9 bulan.

\section{Pemberian ASI Eksklusif}

Berdasarkan hasil penelitian yang disajikan pada Tabel 4, didapatkan bahwa pada kelompok kasus sebesar 52,63\% balita telah mendapatkan ASI eksklusif dan $47,62 \%$ balita lainnya tidak mendapatkan ASI eksklusif. Pada kelompok kontrol sebesar $47,37 \%$ balita mendapat ASI eksklusif dan 52,38\% balita tidak mendapat ASI eksklusif. Berdasarkan hasil uji chi square menunjukkan bahwa tidak terdapat hubungan yang signifikan antara pemberian ASI eksklusif dengan kasus campak (approx.sig $=0,752>0,05$ ).

\section{Riwayat Kontak}

Berdasarkan hasil penelitian yang disajikan pada Tabel 4, didapatkan bahwa pada kelompok kasus sebanyak 15 $(100,0 \%)$ balita melakukan kontak dengan penderita campak sebelum sakit, sedangkan $5(20,0 \%)$ balita lainnya tidak melakukan kontak sebelum sakit dengan penderita campak. Pada kelompok kontrol sebanyak $20(80,0 \%)$ balita tidak melakukan kontak dengan penderita campak.

\section{PEMBAHASAN}

\section{Kondisi Fisik Rumah Pencahayaan}

Hasil penelitian didapatkan bahwa sebagian besar intensitas cahaya pada kamar kelompok kasus tidak memenuhi syarat yaitu kurang dari 60 lux. Variabel pencahayaan memiliki hubungan yang signifikan dengan kasus campak pada balita, dengan OR sebesar 4,5. Hasil penelitian ini sesuai dengan penelitian Sutaryana (2002) yang menerangkan bahwa pencahayaan alami memiliki hubungan yang signifikan dengan kasus campak. Selain itu, penelitian yang dilakukan oleh Casaeri (2003) juga diperoleh hasil pencahayaan memiliki hubungan yang signifikan dengan p-value sebesar 0,04 dan OR sebesar 2,2.

Menurut Setiawan (2008) virus campak akan mudah mati apabila terkena sinar matahari langsung. Menurut Widoyono (2011), virus campak dapat bertahan selama beberapa hari pada temperatur $0^{\circ} \mathrm{C}$ dan selama 15 minggu pada sediaan beku. Pada suhu kamar virus ini akan bertahan selama 34 jam.

Pada penelitian ini, kondisi pencahayaan yang kurang memadai disebabkan karena kondisi rumah penderita campak yang berada di lingkungan sempit dan saling berhimpitan dengan rumah 
tetangga yang lain. Selain itu, kebiasaan masyarakat yang tidak membuka jendela kamar pada pagi hingga siang hari ini juga menjadi penyebab kurangnya cahaya matahari yang masuk ke dalam kamar balita. Saat ditanya lebih lanjut mengenai alasan jendela kamar tidak sering dibuka, sebagian responden menjawab bahwa mereka takut apabila rumah dimasuki oleh pencuri atau orang tak dikenal. Padahal dengan adanya cahaya matahari langsung yang masuk ke dalam kamar balita dapat mencegah pertumbuhan bakteri dan virus khususnya virus campak.

\section{Luas Ventilasi}

Hasil penelitian didapatkan bahwa sebagian besar responden memiliki kamar dengan luas ventilasi tidak memenuhi syarat yaitu kurang dari $10 \%$ luas lantai. Variabel luas ventilasi tidak memiliki hubungan yang signifikan dengan kasus campak pada balita.

Hasil penelitian ini sejalan dengan Budi (2012) dan Mujiati, et al (2015) yang menunjukkan bahwa ventilasi tidak memiliki hubungan yang signifikan dengan kasus campak. Akan tetapi tidak sejalan dengan penelitian Casaeri (2003) yang menyebutkan bahwa terdapat hubungan antara ventilasi terhadap kasus campak pada balita dengan odds ratio $(O R)$ sebesar 2,2 yang berarti kamar balita dengan ventilasi tidak memenuhi syarat berisiko terhadap balita untuk terkena penyakit campak 2,2 kali dibandingkan balita yang memiliki kamar dengan luas ventilasi memenuhi syarat.

Kota Surabaya merupakan salah satu kota dengan kepadatan penduduk tinggi sehingga lahan bangunan pun semakin sempit. Hal ini menyebabkan rumah yang dibangun saling berhimpitan antar rumah yang satu dengan lainnya. Padahal dengan adanya ventilasi yang memadai akan memudahkan pertukaran udara serta cahaya matahari langsung dapat masuk ke dalam kamar balita sebagai upaya mencegah perkembangan virus campak yang mungkin berada di udara (Afdhalash, 2018).

\section{Kepadatan Hunian}

Hasil penelitian didapatkan bahwa sebagian besar kepadatan hunian pada kelompok kasus tidak memenuhi syarat yaitu luas ruang tidur kurang dari $8 \mathrm{~m}^{2}$ untuk 2 orang penghuni. Variabel kepadatan hunian

memiliki hubungan yang signifikan dengan kasus campak pada balita dengan nilai odds ratio $(O R)$ sebesar 10,52.

Hasil penelitian ini sejalan dengan penelitian Sutaryana (2002) yang menyebutkan bahwa terdapat hubungan antara kepadatan hunian dengan kasus campak pada balita di Kabupaten Garut dengan OR sebesar 3,19 yang berarti bahwa kamar balita dengan kepadatan tinggi berisiko terhadap balita untuk terjadinya penyakit campak sebesar 3,19 kali dibandingkan dengan kamar balita yang tidak padat. Penelitian Mujiati, et al (2015) juga didapatkan hasil bahwa terdapat hubungan yang signifikan antara kepadatan hunian dengan kasus campak. Begitu pula dengan penelitian Akramuzzaman, et al (2002) yang menyebutkan bahwa kepadatan hunian yang tinggi dapat meningkatkan risiko pada balita untuk terkena campak sebesar 1,8 kali dibandingkan hunian dengan kepadatan yang rendah. Namun tidak sejalan dengan penelitian Budi (2012) di Kota Banjarmasin yang menunjukkan bahwa tidak terdapat hubungan antara kepadatan hunian dengan kasus campak pada balita.

Seperti yang kita ketahui bahwa Kota Surabaya merupakan salah satu kota padat penduduk yang menyebabkan lahan hunian semakin sempit. Kondisi ini menyebabkan masyarakat tidak dapat membuat kamar dengan jumlah seimbang dengan jumlah penghuni rumah. Rumah yang sempit dengan kepadatan hunian tinggi akan membuat interaksi antar anggota keluarga pun semakin intens, sehingga apabila salah seorang anggota 
keluarga menderita penyakit saluran pernafasan akan mudah pula menular kepada anggota keluarga lainnya. Berdasarkan hasil observasi, sebagian besar kamar dengan luas kurang dari $8 \mathrm{~m}^{2}$ dihuni hingga 4 orang. Menurut Arleni (2014), bangunan rumah yang sempit dan tidak seimbang antara jumlah penghuni dengan luas hunian akan memberi dampak antara lain kurangnya kadar oksigen dalam ruangan yang dapat menyebabkan menurunnya daya tahan tubuh penghuni. Penghuni akan mengalami sesak nafas sehingga memudahkan penularan penyakit dari anggota keluarga lainnya. Pemukiman yang padat juga dapat mempermudah penularan penyakit, kepadatan penduduk dalam memengaruhi terjadinya penularan penyakit diantaranya penyakit campak (Noor, 2006).

\section{Karakteristik Balita}

\section{Umur Balita}

Hasil penelitian ini didapatkan bahwa tidak terdapat hubungan antara umur balita dengan kasus campak. Hal ini sejalan dengan penelitian Casaeri (2002) yang memiliki desain studi kasus kontrol di Kabupaten Kendal, menyebutkan bahwa anak dengan usia kurang dari 5 tahun (usia rentan) berisiko 4,9 kali untuk terinfeksi penyakit campak dibandingkan pada anak dengan usia yang lebih dari 5 tahun. Penelitian yang dilakukan Khotimah (2008) dan Nurlaila (2016) juga menyebutkan bahwa kasus campak paling sering terjadi pada kelompok balita berusia 1-5 tahun dibandingkan dengan balita berusia 0-1 tahun. Namun tidak memiliki hubungan yang signifikan terhadap kasus campak. Artinya kasus campak dapat menyerang siapa saja dari berbagai golongan usia.

Menurut Setiawan (2008), di Eropa Barat, Amerika Utara dan Australia, sebagian besar anak-anak menghabiskan banyak waktu di rumahnya, akan tetapi jumlah penderita campak akan meningkat saat anak memasuki usia sekolah.
Berdasarkan hasil wawancara dengan responden, sebagian besar balita dengan usia lebih dari 3 tahun (37-60 bulan) telah bersekolah, baik itu di Pendidikan Anak Usia Dini (PAUD) ataupun di Taman Kanak-kanak (TK). Menurut responden, anak mereka tertular campak saat berada di sekolah karena ada beberapa teman mereka yang sebelumnya juga terkena campak. Hal ini bisa menjadi penyebab karena virus campak dapat menular melalui droplet saat anak sedang bermain dengan temannya yang menderita campak.

\section{Jenis Kelamin}

Hasil penelitian ini menunjukkan tidak ada hubungan yang signifikan antara jenis kelamin balita dengan kasus campak. Hasil penelitian ini sejalan dengan penelitian Nurlaila (2016) bahwa anak perempuan lebih banyak terkena campak dibandingkan laki-laki, dan sejalan pula dengan penelitian Andriani (2017) bahwa tidak adanya hubungan antara jenis kelamin dengan kasus campak.

Menurut Setiawan (2008) dan Novel (2010), baik pada laki-laki maupun perempuan tidak ada perbedaan kasus serta tingkat kefatalan maupun keparahan penyakit campak meskipun titer antibodi pada perempuan lebih tinggi dibandingkan laki-laki. Baik perempuan maupun laki-laki mempunyai peluang yang sama untuk terkena campak tergantung pada daya tahan atau imunitasnya saat terpapar dengan virus campak. Apabila saat terpapar virus campak imunitas anak sedang menurun maka akan dengan mudah virus campak menyerang tubuh anak begitu pula sebaiknya. Imunitas anak bergantung pula pada status imunisasi anak dan status gizi anak.

\section{Status Imunisasi Campak}

Hasil penelitian ini diperoleh bahwa sebagian besar balita pada kelompok kasus tidak mendapatkan imunisasi campak usia 9 bulan. Berdasarkan hasil uji chi square menunjukkan terdapat hubungan yang 
signifikan antara status imunisasi campak dengan kasus campak, dengan OR sebesar 7,36 . Hal ini menandakan bahwa imunisasi merupakan salah satu upaya preventif untuk mencegah campak (Afdhalash, 2018).

Hal ini sejalan dengan penelitian yang dilakukan oleh Arleni (2014) yang menunjukkan $O R$ sebesar 2,5 yang artinya anak yang tidak diimunisasi campak mempunyai risiko 2,5 kali lebih tinggi terjangkit campak dibanding anak yang telah mendapat imunisasi campak. Begitu pula dengan hasil penelitian Budi (2012), Mujiati, et al (2015) dan Meilani (2013) yang menunjukkan adanya hubungan antara status imunisasi campak terhadap kasus campak. Penelitian yang dilakukan Hyde, et al (2005) menyebutkan bahwa kasus campak yang terjadi pada rentang usia 1-14 tahun sebesar 59\% tidak mendapatkan imunisasi campak. Menurut penelitian Sudfeld, et al (2010) bahwa imunisasi campak efektif mencegah terjadinya penyakit campak sebesar $85 \%$.

Menurut Handayani (2005), imunitas terhadap campak akan terjadi seumur hidup pada sebagian besar individu, begitu juga dengan imunitas yang terbentuk sebagai akibat infeksi penyakit campak. Infeksi alami yang disebabkan oleh penyakit campak cenderung meningkatkan antibodi yang lebih baik jika dibandingkan dengan antibodi yang terbentuk dari imunisasi campak. Respon selular akan terjadi apabila terjadi infeksi virus, hal ini akan dengan cepat diikuti oleh respon imunitas saat ruam mulai timbul, seorang anak akan masuk dalam kelompok rentan apabila ia tidak memiliki titer antibodi. Terbentuknya titer antibodi karena infeksi campak akan lebih stabil dan dapat bertahan seumur hidup. Berdasarkan survei yang dilakukan pada anak usia 0-5 tahun, diketahui bahwa terdapat status kekebalan terhadap infeksi virus campak.

Menurut Budi (2012), sebagian besar ibu di negara berkembang salah satunya di Indonesia pernah mengalami penyakit campak saat masih kecil, sehingga bayi yang dilahirkan pun memiliki maternal antibodi yang terbentuk terhadap penyakit campak. Akan tetapi kadar antibodi tersebut akan turun terus-menerus seiring dengan bertambahnya usia anak. Hal ini menyebabkan hanya pada usia 6-9 bulan sejak kelahiran, bayi memiliki perlindungan yang optimal. Saat bayi berusia 9 bulan, secara aktif akan terbentuk antibodinya sendiri setelah menerima vaksinasi campak. Dalam kurun waktu 12 hari setelah infeksi campak mencapai puncak titer yaitu kurang lebih 21 hari, IgM akan terbentuk dan dengan cepat akan menghilang, kemudian tergantikan oleh IgG. Imunitas ini akan terjadi seumur hidup pada sebagian besar individu, begitu pula dengan imunitas yang terbentuk sebagai akibat dari infeksi virus campak. Adanya karier campak saat ini pun tidak terbukti. Apabila cakupan imunisasi campak telah lebih dari $90 \%$ maka akan membentuk kekebalan kelompok dan menurunkan kasus campak di masyarakat (Widoyono, 2011). Namun ada pula balita yang meskipun telah diimunisasi campak tetapi tetap terkena campak. Hal ini dapat disebabkan karena pada saat anak terpapar virus campak, imunitasnya sedang lemah sehingga ia mudah terserang virus campak. Umur pemberian vaksin juga akan memengaruhi terbentuknya antibodi, umur yang paling tepat untuk imunisasi campak yaitu pada usia 9 bulan (WHO, 2017).

\section{Pemberian ASI Eksklusif}

Hasil penelitian ini menunjukkan bahwa sebagian besar balita tidak mendapatkan ASI eksklusif usia 0-6 bulan. Berdasarkan hasil uji chi square menunjukkan bahwa tidak terdapat hubungan yang signifikan antara pemberian ASI eksklusif dengan kasus campak.

Air susu ibu (ASI) merupakan sekresi kelenjar payudara ibu berupa emulsi lemak dalam larutan protein, laktosa, dan garam-garam organik yang bemanfaat sebagai makanan utama bagi bayi. Pemberian ASI eksklusif pada bayi berarti bayi hanya diberi ASI saja tanpa penambahan cairan lainnya seperti susu 
formula, air putih, teh dan lain sebagainya. Selain itu, juga tidak diberikan makanan padat seperti pisang, pepaya, bubur susu serta makanan lainnya. Pemberian ASI eksklusif ini dianjurkan untuk diberikan pada bayi usia 0-6 bulan (Rudi \& Sulis, 2013).

Menurut Widoyono (2011), di dalam ASI mengandung lebih dari tiga puluh jenis imunoglobulin yang dapat diidentifikasi. Delapan belas immunoglobulin diantaranya berasal dari serum ibu dan sisanya hanya ditemukan di dalam kolostrum. Imunoglobulin yang paling utama yang dapat ditemukan pada kolostrum adalah IgA, bukan hanya karena konsentrasinya yang tinggi namun juga karena aktivitas biologiknya. IgA yang ada dalam kolostrum serta ASI ini dapat melindungi tubuh bayi dari berbagai macam penyakit infeksi. Selain itu imunoglobulin G juga dapat menembus plasenta dan di dalam darah janin/bayi tersedia dalam konsentrasi yang cukup tinggi hingga usia beberapa bulan, sehingga janin/bayi akan terlindungi dari berbagai jenis penyakit. Beberapa jenis antibodi yang dapat ditransfer melalui plasenta antara lain adalah antibodi difteri, tetanus, campak, rubela, parotitis, polio, dan stafilokokus.

Pemberian ASI eksklusif menjadi sangat penting bagi bayi usia 0-6 bulan sebagai antibodi alami dari berbagai macam penyakit. Akan tetapi masih banyak ibu yang tidak memberikan ASI eksklusif kepada anaknya dengan berbagai alasan seperti air susu tidak keluar, ibu bekerja sehingga anak diberi susu formula, serta pemahaman yang salah mengenai pemberian MPASI sebelum umur 6 bulan.

\section{Riwayat Kontak}

Hasil penelitian ini diperoleh bahwa sebagian besar balita pada kelompok kasus melakukan kontak dengan penderita campak sebelum sakit. Hal tersebut sejalan dengan penelitian Arleni (2014) yang menunjukkan bahwa anak yang memiliki riwayat kontak dengan penderita campak sebelum sakit akan berisiko 15,4 kali untuk terkena campak dibandingkan dengan anak yang tidak melakukan kontak dengan penderita campak. Begitu pula dengan penelitian Casaeri (2002) di Kabupaten Kendal bahwa riwayat kontak memiliki risiko 3,2 kali lebih tinggi dibanding dengan penderita yang tidak ada riwayat kontak dengan penderita campak. Penelitian Akramuzzaman, et al (2002) di Dhaka Bangladesh menyebutkan bahwa hampir separuh dari 206 kasus campak konfirmasi pernah melakukan kontak dengan penderita campak sebelum akhirnya tertular. Begitu pula dengan penelitian Mujiati, et al (2015) bahwa anak yang pernah kontak dengan penderita campak memiliki risiko 3,7 kali untuk terkena campak dibandingkan dengan anak yang tidak pernah kontak dengan penderita campak. Menurut Parker, et al (2006) di Amerika Serikat bahwa riwayat kontak akan mempengaruhi terjadinya kasus campak. Sebanyak 19 orang $(56,0 \%)$ dari 34 pasien terinfeksi langsung oleh penderita campak (18 pasien berkumpul dengan penderita campak sedangkan 1 pasien lainnya karena mengunjungi tetangganya yang sedang menderita campak) dan 13 orang $(38,0 \%)$ tertular langsung oleh penderita campak yang ada di rumahnya.

Hal ini menunjukkan bahwa penularan kasus campak terjadi dari orang ke orang yang mudah ditularkan melalui udara yaitu pernapasan. Menurut Widoyono (2011), campak ditularkan melalui droplet di udara oleh penderita sejak 1 hari sebelum timbulnya gejala klinis sampai 4 hari sesudah munculnya ruam. Pada penelitian ini, sebagian besar balita telah bersekolah di PAUD dan TK, menurut hasil wawancara dengan responden bahwa di sekolah anak mereka saat itu banyak yang terkena campak sehingga anak mereka juga tertular virus campak. Hal ini dapat terjadi karena saat anak bermain dengan temannya yang terkena campak maka akan terjadi penularan melalui droplet, terutama jika imunitas anak sedang menurun maka anak akan dengan mudah terkena campak 
meskipun hanya satu kali melakukan kontak dengan penderita campak.

\section{SIMPULAN}

Berdasarkan hasil penelitian, kondisi fisik rumah pencahayaan dan kepadatan hunian memiliki hubungan yang signifikan dengan korelasi lemah dan sedang, terhadap kasus campak pada balita selama bulan Januari-Mei 2017 di Kota Surabaya. Pada variabel karakteristik anak terdapat hubungan yang signifikan antara status imunisasi campak dengan korelasi lemah, dan terdapat hubungan yang signifikan pula antara riwayat paparan terhadap kasus campak pada balita selama bulan Januari-Mei 2017 di Kota Surabaya. Untuk menjaga pencahayaan kamar balita agar tetap memenuhi syarat, sebaiknya ibu rajin membuka jendela kamar tidur pada pagi hingga siang hari agar terjadi pertukaran udara yang baik atau memasang genting kaca agar cahaya matahari dapat masuk untuk mencegah pertumbuhan virus campak. Selain itu, jumlah penghuni pada masing-masing kamar tidur harus disesuaikan dengan luas kamar. Sebaiknya ibu rajin membawa anaknya ke fasilitas pelayanan kesehatan terdekat untuk mendapatkan imunisasi dan informasi dari petugas kesehatan terkait pola asuh anak sehingga anak menjadi lebih sehat dan tidak mudah tertular penyakit, terutama penyakit campak.

\section{DAFTAR PUSTAKA}

Afdhalash, B.J., 2018, Hubungan Kondisi Lingkungan Rumah, Karakteristik Balita dan Karakteristik Ibu dengan Terhadap Kasus campak di Kota Surabaya, Skripsi, Surabaya: Universitas Airlangga

Akramuzzaman, S.M., Felicity, T.C., Md, J.H., Obaidullah, K.W., Nazmun, N., Darul, I., Narayan, C.S., and Dilip, M., 2002, Measles Vaccine Effectiveness and Risk Factors for Measles in Dhaka Bangladesh,
Journal of the World Health Organization 2002;80:776-782,

Andriani, L 2017, Hubungan Karakteristik Balita, Umur Saat Imunisasi Campak, Riwayat ASI Eksklusif terhadap Campak Klinis, Jurnal Berkala Epidemiologi Vol 5 No 2 hlm 265-275, Surabaya: Universitas Airlangga.[https://doi:10.20473/jbe. v5i2.2017.265-275]

Arleni, 2014, Faktor-Faktor Yang Berpengaruh Terhadap Kasus campak Pada Kejadian Luar Biasa (KLB) Campak Di Desa Segarjaya Kecamatan Batujaya Kabupaten Karawang Tahun 2014, Skripsi. Depok: Universitas Indonesia

Budi, D 2012, Faktor-Faktor Yang Berpengaruh Terhadap Kasus campak Pada Peristiwa Kejadian Luar Biasa Campak Anak (0-59 Bulan) Di Kota Banjarmasin Provinsi Kalimantan Selatan Tahun 2011, Tesis, Depok: Universitas Indonesia

Casaeri, 2003, Faktor-Faktor Risiko Kasus campak Di Kabupaten Kendal Tahun 2002, Tesis, Semarang, Program Pascasarjana Undip Semarang

Dinas Kesehatan Provinsi Jawa Timur, 2013, Profil Kesehatan Provinsi Jawa Timur, Surabaya: Dinkes Kesehatan Provinsi Jawa Timur

Dinas Kesehatan Provinsi Jawa Timur, 2014, Profil Kesehatan Provinsi Jawa Timur, Surabaya: Dinkes Kesehatan Provinsi Jawa Timur

Giarsawan, N., I Wayan Suarta Asmara, Anysiah Elly Yulianti, 2014, Faktor-faktor yang Memengaruhi Kasus campak di Wilayah Puskesmas Tejakula I Kecamatan Tejakula Kabupaten Buleleng Tahun 2012. Jurnal Kesehatan Lingkungan. Vol 4(2): 140-145. Buleleng: Poltekkes Denpasar Handayani, S 2005, Infeksi Campak, Karakteristik dan Respon Imunitas 
yang Ditimbulkan. CDK No. 148. 30-34

Hyde, T.B., Gustavo, H.D., Justina, R.L., Robin, N., Russel, E., Kennar, B., Mailynn, K., Mona, M., Huong, Q.N., Anthony, P.K., Michael, J.O., Nobia, J.W., William, J.B., Daoling, B., Cedric, J.B., Jane, F.S., and Mark, J.P., 2005. Measles Outbreak In The Republic Of The Marshall Islands 2003. International Journal of Epidemiology 35:299 306, Oxford University.

Kementerian Kesehatan RI, 2015, Riset Kesehatan Dasar. Jakarta: Badan Penelitian dan pengembangan Kesehatan Kementrian Kesehatan RI

Khotimah, H., 2008, Hubungan Antara Usia, Status Gizi dan Status Imunisasi Dengan Kejadian Campak Balita, Jurnal Obstretika Scientia ISSN 2337-6120, Rangkasbitung: Akbid La Tansa Mashiro.

Meilani, R., Risna, E., 2013, Faktor-faktor yang Mempengaruhi Kejadian Campak di Puskesmas Purwosari Kabupaten Kudus, Jurnal Keperawatan dan Kesehatan Masyarakat Vol 2 No 1 ISSN:22528865.[DOI: https://doi.org/10.3159 6/jcu.v2i1.19]

Mujiati, E., Rini, M., Anita, R., 2015, Faktor Risiko Kasus campak Pada Anak Usia 1-14 Tahun Di Kecamatan Metro Pusat Provinsi Lampung Tahun 2013-2014, Jurnal Ilmu Kesehatan Masyarakat Vol 6(2): $\quad$ 100-112, Sriwijaya: Universitas Sriwijaya.

Nurlaila \& Nur Hanna, 2016, Karakteristik Kejadian Luar Biasa Campak Pada Salah Satu Desa di Kabupaten Pesawaran Provinsi Lampung, Jurnal Keperawatan Vol XII No 2: pp 185-189 ISSN 1907-0357.

Noor, Nur Nasry, 2006, Pengantar Epidemiologi Penyakit Menular. Jakarta: Rineka Cipta
Novel, S 2010, Ensiklopedi Penyakit Menular dan Infeksi, Yogyakarta: Familia Pustaka Keluarga

Peraturan Menteri Kesehatan Republik Indonesia Nomor 1077 Tahun 2011 tentang pedoman penyehatan udara dalam ruang rumah.

Parker, A., Amy et.al, 2006, Implications of a 2005 Measles Outbreak in Indiana for Sustained Elimination of Measles in the United States, Journal of Medicine Vol $355 \mathrm{pp}$ 447-455.

[https://DOI:10.1056/NEJMoa060 775]

Rudi, H, Sulis Setianingsih, 2013, Manfaat ASI Eksklusif Untuk Buah Hati Anda, Yogyakarta: Gosyen Publishing

Setiawan, M 2008, Penyakit Campak, Jakarta: CV Sagung Seto

Sudfeld, C.R., Ann, M.N., and Neal, A.H., 2010, Effectiveness of Measles Vaccination and Vitamin A Treatment, International Journal of Epidemiology 2010;39:148 155, Oxford University Press,

Suradi, R. dkk. 2002. Penelitian KasusKontrol dalam Dasar-Dasar Metodologi Penelitian Klinis. Sastroasmoro \& Ismael (Editor). Jakarta: CV Sagung Seto

Sutaryana, 2002, Hubungan Kesehatan Lingkungan Fisik Rumah dan Karakteristik Balita dengan Kasus campak Pada Anak Balita di Kabupaten Garut Tahun 2000-2001, Tesis, Depok: Universitas Indonesia Widoyono, 2011, Penyakit Tropis: Epidemiologi, Penularan, Pencegahan, dan Pemberantasannya. Jakarta: Penerbit Erlangga. 